\title{
Nusta Juira's Gift of Quinoa: Peasants, Trademarks, and Intermediaries in the Transformation of a Bolivian Commodity Economy
}

\author{
Andrew Ofstehage, University of North Carolina at Chapel Hill \\ aofste@live.unc.edu
}

\begin{abstract}
Farmers and activists in the Los Lipez region of Bolivia have created a symbolic commons that links their identity, quinoa crop, and work. Since 2005, farmers have worked with regional activists and marketers to create a denomination of origin in order to project their work and connection with quinoa into international markets for their crop. Yet sales certified with the denomination of origin trademark have not significantly displaced other sales to buyers for the national cooperatives or to local intermediaries. Based on 4 months of ethnographic research with growers, local resellers, and leaders of the denomination of origin initiative, this case documents how the Bolivian quinoa market is a composite of varied market channels, interests, and values that inhibit the full realization of any single development approach. However, the complexity that actor agency introduces into commodity circulation results in earnings at different scales, the movement of multiple qualities of quinoa, transactions in formal and informal settings, and a more resilient life sphere of agricultural production.
\end{abstract}

Keywords: life sphere, alternative economies, Bolivia, quinoa, commons, denomination of origin

Fair trade literature often discusses the comparative advantages and disadvantages of cooperatives as an alternative model of work and marketing. Cooperatives are regularly juxtaposed against intermediaries that are variously portrayed as self-serving actors, links to be cut out of a chain, or individuals who may be necessary but are still poor alternatives to cooperatives (Daviron and Ponte 2005; Jaffee 2007). On the one side, you have the cooperative and the values of fairness, on the other, salespeople and private profiteering. This paper will present a movement, based in San Agustín, Bolivia, which frames cooperatives and intermediaries on the same side. At the heart of this Andean agricultural trade is a group of quinoa growers who cultivate a distinctive, large-grain crop. Local political activists have sought to trademark this quinoa production with a denomination of origin (DO) protection and thereby build both profit margins and regional solidarity. However, in any given season, different farmers will sell everything from first-class organic quinoa to poor quality, fourth-class conventionally raised quinoa. A farmer may enter into deferred payment, bulk quantity sales with national co-ops, while his or her neighbor strikes quick cash deals with itinerant intermediaries.

This research documents how the movement to distinguish local quinoa with a DO confronts alternative and not always compatible allegiances to place and to work in southern Bolivia. Yet even if informal, low-margin, intermediary-run market channels undercut the DO effort, such marketing deepens the quinoa economy. These Bolivian farmers demonstrate that the more resilient place-based economies may be those that do not in fact fit any unified, place-based cultural marketing program. A cultural asset such as quinoa may be so broadly embedded that a sign of its health is the very contradictions that emerge in the market and the different jobs that come of conflicting approaches.

\section{Local Livelihoods and International Intellectual Property Laws}

At one level, rural Bolivians face the same issue as other long-established communities: how do people whose lives are connected by history, work, and place defend the potential economic and symbolic value of their customs and interactions? Farmers in diverse regions have responded to the dilemma of defending their community base (Gudeman 1999) while producing for a commodity market by creating DO labels. French wine makers market their terroir and define their wine by how it is produced and where it is produced via the appellation d'origine contrôlée system (Barham 2003). Similar labeling has been implemented in Latin America for Colombian coffee and Mexican tequila to distinguish the particular agricultural, historical, and social aspects of commodity production in different places. Colombian coffee, popularly recognized by the image of Juan Valdez, is marketed for both its taste and the romantic ideal of its small-holder, mountainside farmers (Pendergrast 2010), while Mexican tequila, the oldest recognized DO outside of Europe, is certified for its content of blue agave $(51 \%)$ and production within a specific territory (Bowen and Zapata 2009). In each of these cases, the DO label links agroecology and agricultural practices with a shared history of commodity production. 


\section{Anthropology of Work Review}

DO labeling is gaining the attention of Latin American commodity producers as they capitalize on intellectual property [Trade-Related Aspects of Intellectual Property Rights (TRIPS)] protection by the World Trade Organization and the interest of consumers in values labeling. Intellectual property rights are frequently brought up in development discourse as they relate to biopiracy and the defense of local cultivars against appropriation by international corporations (Shiva 1997). However, farmers and artisans are also using intellectual property rights to protect Polanyi's (2001) "fictitious commodities" (land, labor, and natural resources) from commercialization, and they seek out an economic benefit for this protection (Guthman 2007). A DO label's integrity depends on excluding outside producers and commodities that are not produced in the designated way and depends on a community committing resources to defend their common reputation. The outcome of DO labeling is mixed in Latin America. Mexican tequila, for example, has resulted in decreased economic security, increased use of herbicides, and reduced use of fertilizer (Bowen and Zapata 2009), and Brazilian cheese producers perceive an initiative to certify Serrano Cheese to be undemocratic and fear that it will lead to standardization of production methods (Vitrolles 2011). Elsewhere, in Latin America, Chile and Peru contest the property rights to pisco sour (Tortorelli 2010), and Cuban cigars (Habanos) have 15 appellations of origin, 62 trademarks, and 2 certification marks (Benni and Reviron 2009). Critics such as Julie Guthman claim that in order to go beyond replicating the neoliberal economic model, DO labels must "produce more collectivist political subjects who in time would develop forms of governance more commensurate to the socialized problems before us" (Guthman 2007:474).

In this article, I show how the Bolivian effort to exploit the possibilities of a DO has not fostered a new regional unity with growers upholding a singlebranded crop. Rather, it has added a politicized marketing movement to an already fragmented economic sector. Here, Lorraine Aragon's concept of a "split economy" begins to get at some of the complexity one finds in southern Bolivia (this issue). Split economies are "local production processes that serve an internal ritual or 'embedded' social purpose, entailing family or group-based delayed reciprocity, and an external commodity market, entailing monetary payment from some kind of 'outsiders'" (Aragon 2001). Quinoa farmers in San Agustín do not produce separate stands of quinoa for different economies, but they do split their quinoa among fundamentally different ends. Portions are saved for household consumption and seed and the quinoa that is sold is distinguished by the purpose of that sale (e.g., to earn a profit, to barter for potatoes, to pay for a funeral, or to maintain the quinoa's identity). In the case of salmon fishermen in Kamchatka (Gerkey 2001), salmon fishing networks represent separate markets for commoditized fish and locally embedded forms of production. The difference manifests itself in the method of harvest and the means by which it circulates, not by inherent properties of the product. Drew Gerkey's study of salmon fishing demonstrates something that classic cases of DO (e.g., Barham 2003) do not address: a commodity is not only defined by how it is produced and by whom it is produced, but by how it circulates in the economy.

In Bolivia, the forms of production and exchange - not the grain itself - set up the crucial cultural differences that become the foundation of value. The quinueros (quinoa farmers) of San Agustín have embarked on a mission to differentiate their quinoa. This is a process by which actors link the well-known physical differences of their product to particular claims about how they work the land and how that work itself makes visible inherent qualities of the region's population. That is, the value of their crop is not just that it is large-grained, or that it is from a special place, but that it is rooted in a very human skill and labor. The achievement of the quinueros and the intermediaries is to have used the DO movement to elevate the political and cultural importance of work and land making them into a wider resource for alternative economic development.

In developing this point, I will raise a second pressing question: how far has this symbolic value been defended and used by quinoa farmers? The short answer is not very far. Local vendors, small-time intermediaries, and other actors within Los Lipez have not all fallen in line with the DO movement. There is little surprise here. Throughout Latin America, cultivators, intermediaries, and others have, in fact, formed varied trading relations for coffee, quinoa, and other crops, practices that materialize different values and interests (Arce 2009; Ofstehage 2010). Precisely because of the incommensurable aspirations of all the different actors who raise crops and bring them to market, Alberto Arce has argued for thinking beyond commodity chains or market segments and speaks of "life spheres," or "entities whose composition, mixture, and aggregation convey the idea of unity without them constituting a 'totalitarian' whole" (Arce and Long n.d.:6). The term can be understood as a kind of semi-shared lifeworld, a group of actors who form a single entity (a separable unit in contrast to other units) without being homogeneous in composition or ideals. Life spheres connote a level of coordination among actors with similar characteristics. Additionally, life spheres can provide a middle ground between flat organization (i.e., networks) and vertical organization (i.e., systems), and the concept allows for class- 


\section{Anthropology of Work Review}

based, kin group, gender, and ethnic differentiation. In absence of a homogeneous social class, kin group, gender, or ethnicity, life spheres are often centered on a common economic activity - quinoa production, for example. The loosely based organization of actors around an economic activity can then be cultivated for economic or political value as will be described later in this paper.

\section{Research Methods}

Research was conducted using roughly 70 semistructured interviews as well as extensive participant observation of quinueros and rescatiris (quinoa middlemen). During 4 months of research, I met with comerciantes (market vendors) in Cochabamba, Challapata, Sucre, Potosí, Oruro, and Uyuni and conducted participant observation with farmers in San Agustín and a middlewoman who procured quinoa in the area. Research was directed at the pathways of quinoa through the domestic market in Bolivia and the meanings of market transactions to quinoa farmers. ${ }^{1}$ I begin with a discussion of the regional/political circumstances against which the DO movement has developed. I then review cultural tales and ecological conditions that give quinoa such a distinctive local profile.

\section{Regional Economy and Identity in San Agustín}

For all the places I've walked, a plant very resistant to cold and frosts will have a very long height and its fruit will have an extraordinary ability to combat hunger, cure sicknesses and will be resistant to droughts. You are all a strong and intelligent people.[Nusta Juira, The Legend of Quinoa]

Quinua real is produced exclusively in the Southern Altiplano of Bolivia within close proximity of the salt flats of Uyuni and Coipasa, within the departments of Potosí and Oruro. Quinua real is often translated as "royal quinoa," but according to farmers in the region, it is more accurately translated as "real" or "true" quinoa (Laguna 2010, personal communication). ${ }^{2}$ Los Lipez (see Figure 1) is a significant quinoaproducing region within this area. This territory was considered a semi-autonomous region before Bolivian independence in 1825 but was then integrated into the nation and later divided into several provinces. ${ }^{3}$ Los Lipez is relatively isolated from the administrative national capitol of $\mathrm{La} \mathrm{Paz}$, the constitutional national capitol of Sucre, and the regional capital of Potosí. The economic and transportation center of the region, Uyuni, is 5 hours away by speeding bus and 10 to 12 hours by truck. This isolation is not only felt economically, but manifests itself politically as Lipeños (the people of Los Lipez) feel relative autonomy from the national and state governments.
Since the 1980s, the people have responded to the difficulty of political and economic reform through their tried and true method of political action: train blockades. Besides producing quinoa, Los Lipez is home to significant mineral wealth, and the train services operate to bring minerals from Lipez and the Potosí area to international seaports in Chile. The region has blockaded trains in the past to call attention to underdeveloped transportation and communication infrastructure in the region, poor passenger train service in the region, and lack of benefit from local mining operations (VictorRagonese and Quisbert-Salinas 2005; Bautista Muraña et al. 2006). In April 2010, more than 1,000 Lipeños united at the Bolivian border town of Avaroa to stop all trains leaving the country via that route. The blockade was meant to call attention to the lack of highway development and the lack of cell phone availability but centered primarily on the tremendous environmental destruction brought by mining operations and their lack of local economic benefit. The mining operations' limitless use of water touched a particularly sensitive nerve because of the recent droughts in the area that had limited quinoa harvests and killed off portions of llama herds. These protests and blockades are a telling example of the political unity of the Lipeños. Although one cannot say that the entire region's population is united under a common identity, identity is in fact a significant influence on the actions of the people. As leaders have sought out greater political and economic relevance, they have formed the Mancomunidad de la Gran Tierra de Los Lipez. The organization is a continuance of other efforts in the region to govern insiders and outsiders and the business of quinoa has been central to the history of this activism.

In the 1980s, for example, many communities formed committees in defense of quinoa. These local entities were formed in response to the increasing presence of rescatiris in the area who purchased quinoa to sell in regional markets or to export to Peru. Committees in defense of quinoa were not uniform in mission or practice, but most sought to govern the activities of intermediaries through taxation or other means and by periodically leading missions to open up market opportunities. These committees followed the founding of Central de Cooperativas Agropecuarias "Operación Tierra" Limitada and led to the formation of the Asociación Nacional de Productores de Quinua (ANAPQUI), the two national quinoa farmer cooperatives in Bolivia.

The Mancomunidad is both an extension of the cooperatives and a separation from that earlier movement. It shares much of the economic rationale and solidarity principles of a cooperative through its efforts to create a stronger regionally based economy and as 


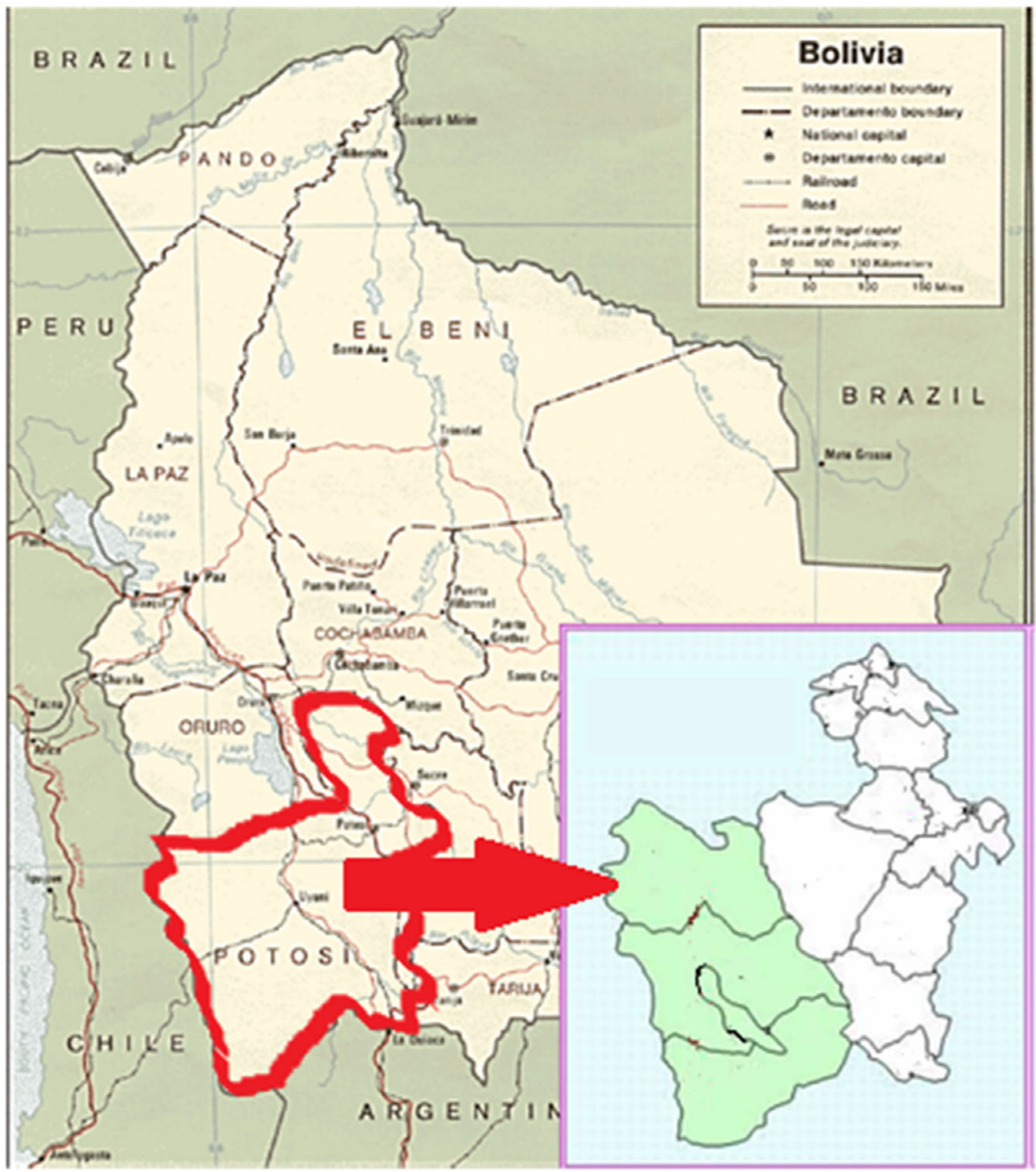

Figure 1. Map of Los Lipez. ${ }^{14}$

a regional unit of political organization. However, it distinguishes itself through differentiating a regional grouping of farmers from the mass of Bolivian quinueros of all regions. The organization seeks to unite the quinueros of Los Lipez under a common identity and a common performance of agriculture - that is, an explicit, shared ethos of nonmechanized farming - thereby differentiating Lipeña quinoa from all other types. The Mancomunidad, in other words, can be interpreted as a method of re-embedding the quinoa trading economy with farmer identities. One of the ways they do that is to revalue quinoa to include both the farmers themselves and the labor that they perform.

Volume XXXII, Number 2 (C) 2011 by the American Anthropological Association. All rights reserved. 106 


\section{Anthropology of Work Review}

The process of differentiating Lipeña quinoa is spearheaded by the Consorcio de Lipez, a consortium created by the Mancomunidad and tasked with commercializing Lipeña quinoa, finding markets, and establishing a DO. The origin is not only based on the contemporary practices and identities of quinoa farmers, but on a long and winding history of quinoa production in the region. ${ }^{4}$ For people in Lipez, their quinoa has different mythological origins, different needs as a crop, and taps farming traditions in contrast to those in other places.

The legend of Mama Thunupa is one of the foundational tales of differentiation of Lipeña quinoa. The legend tells of a time when a terrible drought affected the Southern Altiplano, causing famine and widespread disease. The people of the area prayed to their god, Mama Thunupa, to send rains and food; Mama Thunupa sent another god, Nusta Juira, to end the suffering. ${ }^{5}$ Nusta Juira walked through all of the Southern Altiplano, saying that she was sent by Mama Thunupa to end the drought and the famine, but was received differently throughout the area. In the north, people doubted her provenance and she was received coldly; farther south, people received her warmly but still with doubt. In the far south, in Los Lipez, she was received as a god and treated as such. People followed her and praised her. At the end of her journey, she said, "For all the places I've walked, a plant very resistant to cold and frosts will have a very long height and its fruit will have an extraordinary ability to combat hunger, cure sicknesses, and will be resistant to droughts. You are all a strong and intelligent people." She then ascended to be with Mama Thunupa again. The plant that she left was quinua real; where she had been coldly received, she left a short plant that would be sufficient to feed the people, but in Los Lipez, where she was received warmly by believers, she left the largest and most nutritious grain to honor them.

What, besides the myth of Mama Thunupa, makes Lipeña quinoa different? The quinoa of Los Lipez is most commonly associated with its physical environment, and this factor permeates through much of its differentiation from other regions' quinoa. ${ }^{6}$ Lipeña quinoa is produced at an average altitude of $13,000 \mathrm{ft}$ and within close proximity to the salt flats of Uyuni. Despite its marketability, the crop is produced in only a small number of geographical areas due to a lack of suitable agroecosystems. Quinoa requires a specific quality of light to produce flowers, and eventually, seeds; this quality of light is found at high altitudes and is aided by saline soils that can reflect a certain amount of light from the ground. The environmental properties of Lipez translate into what is recognized as the largest quinoa grain on the market. Quinoa consumers in the North and in Bolivia prefer larger grain size, either for its visual quality or because larger grains can be better used to elaborate specific products, such as pipoca (popped quinoa).

The topography of Los Lipez is quite hilly, which means two things for quinoa production - limited use of mechanization and insurance against poor weather. Tractors are not meant for steep inclines; therefore, production in the hills of Los Lipez is necessarily manual. The availability of multiple agroecosystems (hillsides and flatlands) also allows a certain level of insurance against poor weather. A rainy year, for example, may result in quinoa-killing frost on the hillsides but good production in the dry lowlands; a dry season is unlikely to yield significant production in the flatlands, but the valuable soils on the hillsides may be better off.

Two other factors, the altitude and the aridity, make organic production more feasible in Los Lipez than in other regions. The altitude translates into much colder weather and therefore reduced pest problems. While quinoa farmers in other regions may require the use of organic pesticides, Lipeña farmers may not require any application, at least on the hillsides where temperatures are colder. The aridity of the soils, especially on the flat lands, limits production to one harvest every 3 to 10 years in order to allow sufficient replenishment of soil nutrients and moisture; this fallow system disrupts the lifecycle of many pests, thereby further reducing the need for chemical applications.

The result of the climate and topography of Los Lipez, or at least of the region surrounding San Agustín, is a unique set of agroecological practices. ${ }^{7}$ The distinctive terrain is complemented by a set of farming practices that are self-consciously embraced as part of what makes the region special. Indeed, Lipeño farmers are proud of their distinction of using "traditional" farming techniques in contradistinction to other farmers' use of mechanization and increasingly industrialized farming. Planting is often done by hand, plants are protected using local plant extracts and natural pest barriers, fertilizer is often derived from animal waste, harvesting is done manually, and threshing is laborious (see Figure 3). In comparison, Lipeño farmers contend, farmers from the Challapata area use weed wackers to cut quinoa stalks, mechanical threshers, and tractors for planting and tilling. Of course, farming practices vary from place to place regardless of the product or region; farmers make use of their local agroecological knowledge and environment by tailoring their practices accordingly. What is distinct about this case is that these practices are being used to distinguish the crop on multiple levels. Quinoa Lipeña is marketed as a special grain for its cherished size. Given current market tastes in urban Bolivia, it is also promoted for its "organicness." But increasingly, 


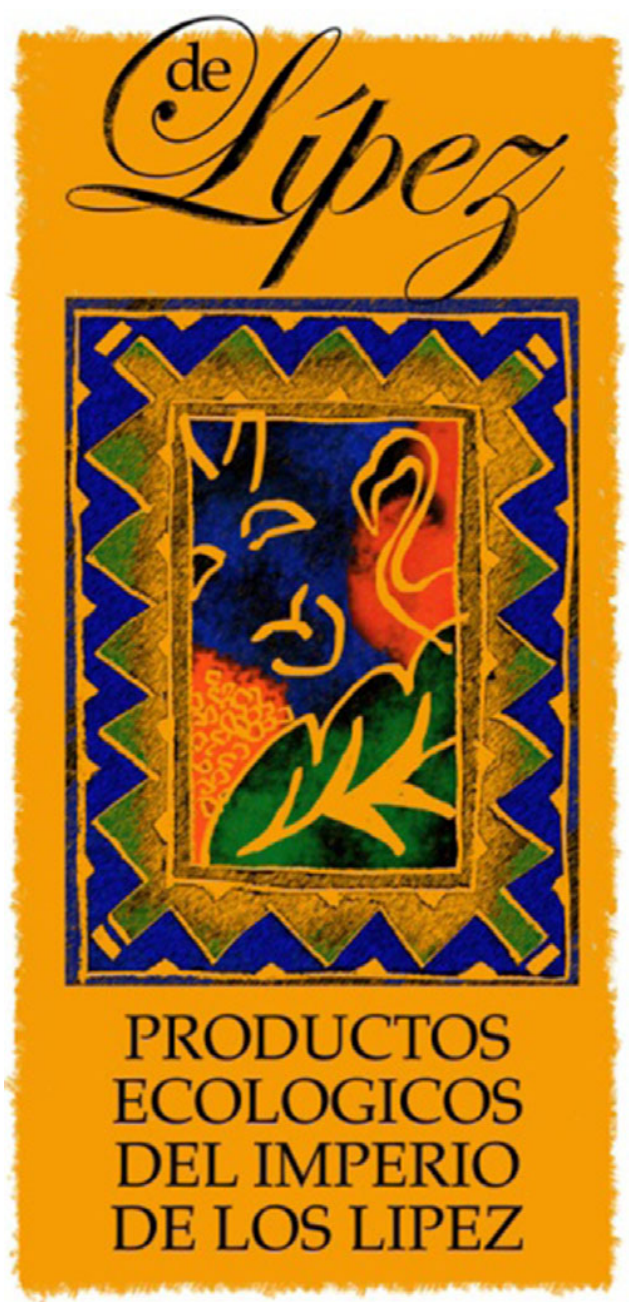

Figure 2. Mark of the denomination of origin for Los Lipez.

it is marketed as a food produced by Lipeño quinueros. In other words, the farmers' performed work is re-embedded into the commodity in order to draw an exclusive socio-territorial boundary around the grain.

Quinua real's different farming traditions and physical qualities now combine with more recent efforts to politicize the Lipeña identity to coalesce into this initiative to create a sello de origen (DO) for Lipeña quinoa. In 2005, the Mancomunidad de la Gran Tierra de Los Lipez formed the Consorcio de Lipez to lead the movement toward a DO. The consortium sought to capitalize on the real and perceived difference between Lipeña quinoa and quinoa from other regions both to make an agricultural product that could earn higher prices, and a political region that commanded more national respect. The initiative for certification came from local activists working with the Mancomunidad, and small funds were provided by a Danish nongovernmental organization. As part of the trademark effort, the consortium first gained organic certification

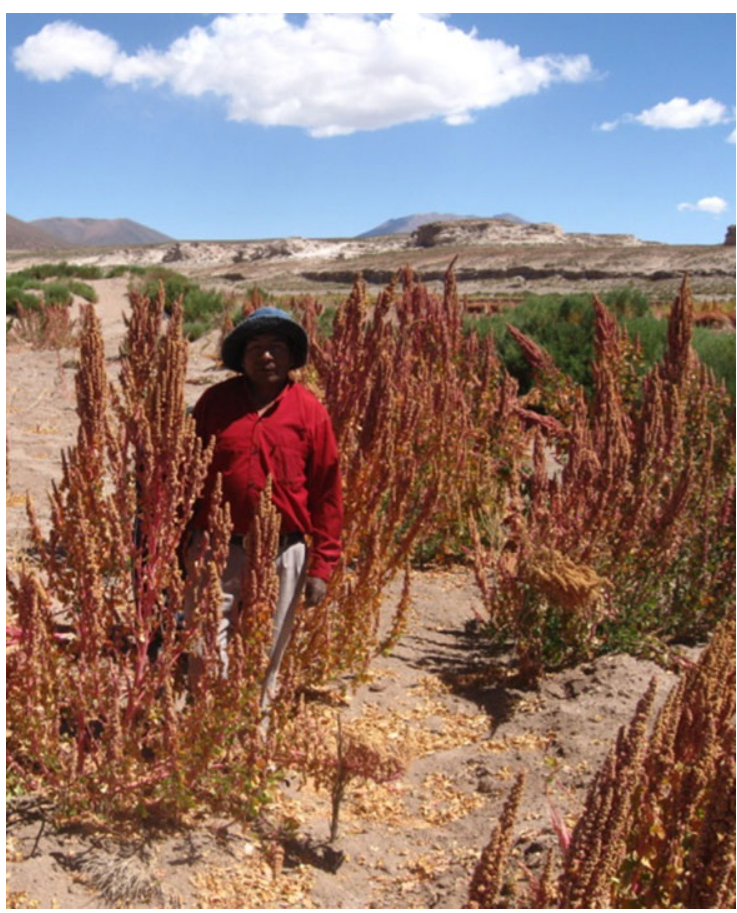

Figure 3. Quinuero of Lipez, harvesting.

in 2008 through Bolicert. Then, after extensive tramite (bureaucratic paperwork) in La Paz, the National Intellectual Property Service of Bolivia granted the Mancomunidad a DO for "quinua real de Lipez" on November 25, 2009 (see Figure 2). The initiative now involves local farmer organizations in the region as primary material suppliers and several microbusinesses scattered through the region, which process the materials into finished products. ${ }^{8}$ The complexity of linking farming, cultural, and marketing strategies is related, in fact, to the way farmers themselves see all three issues linked in the acts of cultivation and exchange of their crop.

Many of the quinueros in San Agustin spoke of the DO in terms of identity and of ownership, thereby demonstrating their intimate concern for the social labor, cultural know-how, and personal sacrifices that is materialized in their quinoa. Rather than focus on the physical qualities of Lipeña quinoa, farmers often explained that the difference between their production and that of other regions was the work performed by Lipeño farmers. Lipeño quinueros were said to use manual labor in planting, harvesting, processing, and protecting their quinoa while other regions' producers used tractors. They argued that in producing quinoa, they were using more-than-organic practices and recreating traditional farming practices - both initiatives, they thought, should distinguish their product.

Furthermore, they saw their own identities as embedded in the quinoa, even after its sale. They 


\section{Anthropology of Work Review}

complained that their quinoa's identity was under constant threat. It could be purchased by intermediaries, mixed with quinoa from different origins, sold in Challapata, mixed again, sold in Desaguadero, brought across the border to Peru, mixed again, and then finally sold in a Peruvian market as Peruvian quinoa. Each mixing of the quinoa and each transaction is a point of lost identity, but the ultimate insult is that this quinoa, painstakingly produced on the Lipeño hillsides by San Agustín quinueros, could be passed off as Peruvian. Interestingly, this fear of lost identification with their crop links two great controversies of Bolivia. The first entailed the petition by a U.S. professor to patent a Bolivian quinoa gene for its use by Colorado State University - thereby appropriating ownership of the plant. The second involved a statement by Miss Peru that La Diablada, a feature of the Carnaval de Oruro and symbol of Bolivia, was a traditional Peruvian dance - an act of co-opting what may be the ultimate example of Bolivian culture.

Even selling to a local cooperative was viewed as a loss of the quinoa's identity - the local cooperative, Proyecto del Centro de Desarrollo Integral K'uichi aggregates the local production and sells it to ANAPQUI in Challapata where it is rumored to be mixed with other cooperatives' quinoa. The president of ANAPQUI denied this to be true, but acknowledged that the quinoa was sold as Bolivian, not specifically Lipeña. The unbreakable bond Lipeña growers feel for their grain recalls Marcel Mauss' proposition that products may remain linked to the people who produced them even after they are traded (Mauss 2002). In southern Bolivia, the producer leaves part of his identity within the product and expects this identity to be recognized by the product's future owners. The identity of the quinoa is a kind of re-embedding of the social into the market, or a devirtualization (Miller 1998, 2002) and a concomitant visualization of labor, history, solidarity, and identity. Just as the marginalized residents of the Cochabamba barrios both administer local justice and make a violent show of administering justice (Goldstein and Castro 2006), quinueros from Lipez farm and make a performance of farming in order to make their voice heard and to project their identity outwardly. A re-embedding of farmer identity into the commodity has potential to foment solidarity within the greater Lipez community while simultaneously projecting the individual farmer's identify in the form of performed work.

The cultural political movement to separate Lipeña quinoa from other types can be juxtaposed against the need to make money in an undifferentiated global market for quinoa. ${ }^{9}$ One side is the personal and political value of "traditional" and "more than organic" and "god-given" quinoa production.
The other is driven by a desire to protect a profit margin and deliver the necessary cash incomes. Embracing market principles, many growers within the movement called for the DO to align the market value of quinoa with the perceived historical and cultural values. The greater market value serves as a kind of confirmation of the special performed work of quinueros. Further, the separation of Lipeña quinoa from other quinoa markets is a political mission by itself. The economic benefits would be significant if local growers could independizarse (become independent) from national cooperatives and local intermediaries as the movement would like to do in the long term. The impact would also elevate the stature of the organizations that could promote and maintain the DO.

\section{An Alternative, Alternative Economic Sphere}

The movement for the DO offers a powerful tool for building the fortunes of the growers of Lipeña quinoa growers, bringing together farming, culture, and politics in a novel way. Farmers, though, have not unanimously lined up to support the initiative. Some continue to support the national cooperatives because of their role in creating opportunities in the quinoa market and for the relation that the coops have built with northern buyers over nearly 30 years. Others see the flow of quinoa to market as unrelated to their attachment to the quinoa. If quinoa is an essential part of life and family, it is also a cash crop to be disposed of expeditiously. Furthermore, it is a varied cash crop of different grades, with some of it organically produced and other quinoa yields preserved by fertilizers and pesticides. Some farmers grow for speculative earnings, others as a hedge against other jobs, and still, others grow just enough for household consumption and seed.

The complexity of this economy has often been overlooked in work on Andean agriculture. Scholars tend to polarize the Andean peasant economy, insisting that it is either dependent upon nonlocal commodity markets (Blum 1995) or autonomous and meant for nonmarket purposes (González de Olarte 1994). ${ }^{10}$ Furthermore, the literature on Bolivian agrarian production often emphasizes alternative relations of production based on reciprocity and the ayni (a type of sociopolitical organization) organized between households. Thus, market relations appear starkly as outside forces, while the agency of the men and women who cultivate crops in the Andes seems intractably local and bound to their fields and patios. What is missing in world and regional production theories such as those of Volkmar Blum and Efraín González de Olarte is recognition of the actor's market agency on the local level. Indeed, individual actors are capable of not only interpreting the national 


\section{Anthropology of Work Review}

markets for their interest, but transforming local commodity exchanges so that they implement their values and interests (Ofstehage 2010). What is often at work as people move their produce into market channels is not something that can be abstractly thought of as development and commercialization, but grounded interests of communities and the powerful identification of individuals with their work and localities. The DO movement is one expression of a group of farmers remaking their options within a commodity economy. Yet it has not replaced the work of national cooperatives just as the cooperatives did not eliminate the original local intermediaries.

Although intermediaries were known in the 1970s and 1980s as untrustworthy economic actors, many of them today are quite careful to present themselves as scrupulous in practice and trustworthy in nature. They also work to solve provisioning and cash flow problems that beset the household economies of small farmers. The relative isolation of San Agustín creates a myriad of practical issues for the inhabitants of the town. Fresh fruit is difficult to find in San Agustín, save for walnut-sized apples from a small tree. Banking services are nonexistent, and household items are in low supply and come at a high cost. Local shop owners trade in essential food stuffs and household necessities, but residents must travel to Uyuni to find a selection of inexpensive goods and to access savings and loans at bank branches. The trip not only takes 5 hours, but bus service is intermittent at best. The scheduled service leaves on Friday afternoon and returns Monday morning if, that is, the roads permit, the driver is sober, and there are enough passengers to justify the trip. Cash is also relatively difficult to come by in San Agustín. Payments from the local cooperative can be delayed for several months, and savings can often be insufficient for "special events" such as town festivals, weddings, and funerals. During the preharvest months of February, March, and April, cash is particularly difficult to find. In this isolation, intermediaries have found a strategy by which they can make themselves useful or perhaps necessary to local farmers. ${ }^{11}$

Isabella Salvatierra is one such entrepreneur who specializes in bringing goods and cash into San Agustín in exchange for quinoa. ${ }^{12}$ Isabella is an originaria (original habitant) of San Pedro de Quilmes, a town within the region of Los Lipez and somewhat near to San Agustín. She began her trade as a means of leaving the house, reacquainting herself with old friends, and earning a small amount of spending money. With changes in the quinoa market and her personal life, she has joined numerous other women as a full time intermediaria (middlewoman). In fact, most small-scale intermediaries are women so taking on the work itself followed precedent. She converses in

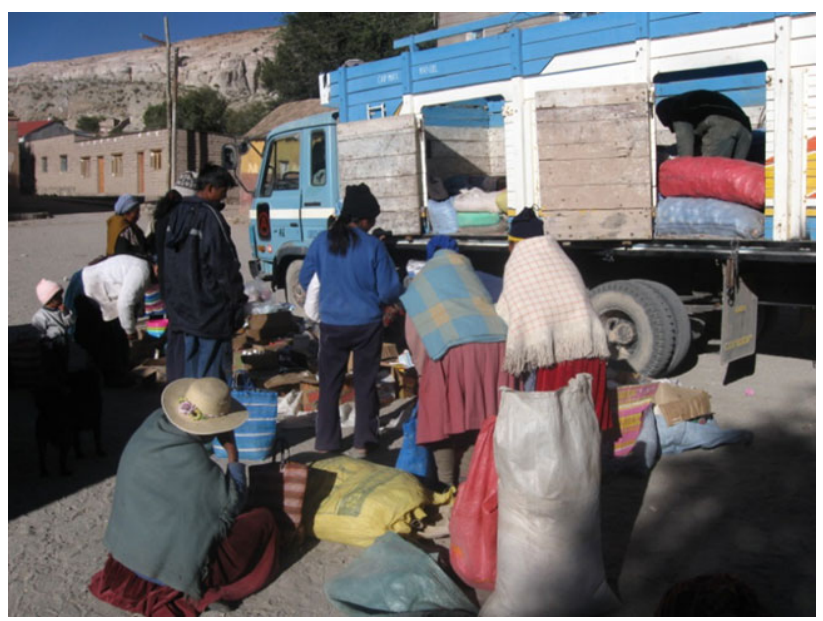

Figure 4. Isabella Salvatierra at work in the San Agustín Plaza.

Quechua or Spanish as the customers prefer and spends much of her time in San Agustín, not hawking her goods, but commenting on life in Uyuni, inquiring about her brothers-in-law or godchildren in the community, and chastising local drunkards, much to the boredom of her daughter.

An inescapable element of Isabella is her semirootedness in San Agustín. Economists often present intermediaries as working at the margins of the formal economy (Daviron and Ponte 2005), while anthropologists have been more apt to consider the roles of middlepersons in rural communities (Buechler and Buechler 1996). As a resident of Los Lipez and a Quechua speaker, Isabella is simultaneously an insider and an outsider in her role as middlewoman. This dual citizenship and role as an outsider enable Isabella to capitalize on price movements in the quinoa market and to secure a dependable through a close relationship with many of the inhabitants. While collecting quinoa and selling her goods in several towns, Isabella offers to me offhand remarks on what she expects in each town.

Isabella's particular expertise lies in grading and pricing quinoa quality at the lower end of the spectrum (see Figure 4). Individual fields are either organic or conventional, but all fields contain a mix of grades of quinoa - these are first class, second class, and so on. ${ }^{13}$ The different grades separated through the threshing process are defined by the size of the grain and the presence of foreign matter. First-class quinoa is large-grained and contains very few other seeds; second-class quinoa is slightly smaller and contains a good deal of other seeds and possibly pebbles. Fifth-class quinoa, which is quite rare, appears to be more stem and dust than quinoa. The quality of a harvest (the portion of the harvest that is high 


\section{Anthropology of Work Review}

quality) depends on the productive elements (rainfall amounts, damaging winds, severity of frosts) - a good producing year will yield a higher percentage of firstclass quinoa - but all harvests will include some portion of low-quality quinoa. Isabella quickly determines the quality of quinoa by running her fingers through a sample, and her experience working in the region allows her to predict where she will find highclass quinoa and how much of it will be for sale. Colcha " $K$ " always has high- to moderate-quality quinoa, but little available for sale, San Agustín is known for the highest quality and the greatest quantity of quinoa in the area, and Copacabana has the lowest quality, but plenty of it. The reason for these community-level differences in high-quality quinoa availability was not clear, but it is most likely a combination of agroecological factors (productivity) and local market factors (relative access to quinoa buyers, etc.).

Despite Isabella's ability to communicate in Quechua and her extensive personal history in the region, her identity as a trusted local is not given but depends upon her performance of that role. Just as quinoa farmers seek to differentiate themselves, Isabella must create a reputation as an honest and fair woman with intricate ties to the region. Her relationships in the community are maintained by her participation in local festivals and her continued interest in friends and relatives in the area. Her actions as a middlewoman also support the perception of Isabella as an honest woman. She uses a single scale for weighing purchased quinoa and sold goods - ensuring that quinoa is not underweighted - and she also provides several services that are necessary to the day-to-day well-being of quinoa farmers. Besides selling a variety of relatively cheap goods, Isabella provides a kind of mobile banking service. Quinoa is exchanged for small sums of cash as an urban dweller might use an automated teller machine, credit is provided for an upcoming harvest as a kind of microloan, and U.S. dollars can even be exchanged for Bolivian bolivianos - these services allow farmers to maintain cash reserves prior to harvest or in between payments from the cooperative.

For all their rootedness in the community, Isabella and the many middlewomen perform a basic task of an international commodity market. While the mission of the Consorcio de Lipez is to differentiate Lipeña quinoa, the practice of intermediaries is to fundamentally standardize quinoa. Intermediaries have neither the capacity nor the capital to certify their quinoa as organic, fair trade, or Lipeña. Instead, the buyers make a simple discrimination according to a limited set of features. Quinoa is separated by size and purity with little regard to production practices or local conditions.
Intermediaries, then, are simultaneously of great use to San Agustín quinoa farmers and working against the farmers' efforts toward differentiation. They offer farmers ready cash, help provision households with consumer basics, break the economic isolation of rural places, and generally make the farming economy more versatile through purchasing otherwise unsellable harvests. Their ancillary economic services make them a durable part of the complex assemblage of buyers and sellers that has emerged following the economic rise of agricultural cooperatives, the taming of intermediaries, and the growing interest in a DO. The ways in which intermediaries buy and sell quinoa - mixing different regions' harvests together, not distinguishing organic from conventional, and "lengthening" food supply chains (Renting et al. 2003) - are antithetic to the vision of the efforts of the consorcio. Yet, the consorcio members would be even harder pressed to make their way in global markets without women such as Isabella adding resiliency to the quinoa life sphere.

\section{Preliminary Gains and Costs of a New Market Channel}

The movement toward a separate market for Lipeña quinoa requires an investment by local farmers to consistently produce a distinct product as well as a commitment to reduce sales to conventional market flows. Its success depends on farmers' ability to exclude quinoa that is produced in an insufficiently "traditional" manner, quinoa produced in other regions, and quinoa that does not meet the high physical quality standards of the DO. The emphasis on regional identity and pride in work has helped to build an alternative model to the global market as well as making workers increasingly visible. Indeed, from the grower's point of view, the DO, more than anything, is based on the skilled labor, human touch, and practiced knowledge of local farmers embedded in the quinoa. Through the DO, quinoa farmers in San Agustín have given a legally protected marketing identity to their use of "traditional" agroecological practices. Whether this transformation will be limited to a supplemental alternative to national cooperatives and intermediaries is yet to be seen. What is significant is that local actors have again shown the ability and the desire to reshape the economy through their agricultural and political practices.

In the last 20 years, the growing prominence of the quinoa market has increased political activity in the region and allowed the citizens of Los Lipez to present a relatively united front. A potential benefit of this movement could be increased political power and increased access to state resources. The potential of quinua real de Lipez DO reflects Guthman's (2007) call for DO initiatives to create a new form of eco- 


\section{Anthropology of Work Review}

nomic governance. A principle goal of the movement is to create a regional economic model in which the market has a role, but the people are the central element and their work is valued at more than only the market price of their products. It is undeniable that Lipeño quinueros stand to benefit economically if this development eventually succeeds. Not only would the quinoa achieve a greater market price, but it would be accompanied by a greater share kept by local entities and farmers if national cooperatives and intermediaries are displaced.

The movement, however, faces a steep climb toward success. Support in San Agustín was split roughly evenly between those who preferred the status quo and those who were interested in greater independence from national cooperatives and local intermediaries. Many of both groups preferred a mix of the two. Indeed, the DO is likely to survive as a part of the existing assemblage of buyers and sellers of quinoa in Los Lipez.

Consistent with the concept of split economies, the creation of a DO will not likely completely replace other flows of quinoa to local resellers or national cooperatives but may create a multichanneled economy in which distinct movements of crop sales exist and supplement each other. These exchanges will continue to influence and spill over into one another continuously, diversifying livelihoods and creating a rich, contemporary agricultural life sphere.

\section{Acknowledgments}

I would like to thank Alberto Arce and Pablo Laguna for their insights and advice throughout my fieldwork and Rudi Colloredo-Mansfeld for his comments on several versions of this article. I also appreciate the valuable comments given by the two anonymous reviewers and Michael Chibnik.

\section{Notes}

1 See Carlos-Aroni, Juan, María Cayoja, and Marco A. Laime. 2009. Situacion Actual al 2008 de la Quinua Real en el Altiplano Sur de Bolivia. Potosí - Oruro: FAOTAPO for economic figures on the quinoa trade.

2 In this article, quinoa refers to the crop in general, including quinua dulce and quinua real. Reference to quinua real refers to the specific type grown around the salt flats of Uyuni and Coipasa.

3 Los Lipez is composed of four provinces: Nor Lipez, Sud Lipez, Enrique Baldivieso, and Daniel Campos.

4 This is not to say that there is a uniform history of quinoa production in Los Lipez. For example, quinoa has been produced in San Agustín for only 50 years, while production in other parts of the region began centuries ago.

5 "Juira" is Aymara for quinoa.

6 To be clear, in speaking of Lipeña quinoa, I am referring to the representation of Lipeña quinoa put forth by the proponents of the denomination of origin (DO). It is clear from my own research and from conversations with Pablo Laguna that quinoa is produced, consumed, and sold differently in different areas of Los Lipez and within communities (Ofstehage 2010). Thus, while I refer to Lipeña quinoa as a general term, I do so for the sake of readability, not with the intention to project standardization on the Lipeño farmers and Lipeña quinoa.

7 This section is presented from the point of view of the DO, not as a representation of the differentiation of farming practices in San Agustín or in greater Los Lipez.

8 The consorcio sells a variety of products besides quinoa, including llama jerky, llama wool, salt from the Salar de Uyuni, and medicinal teas.

9 I refer here to quinoa that is undifferentiated according to regions and specific agroecological practices. Quinoa is, of course, differentiated as quinua real - other types of quinoa and organic - conventional. Some are also sold as fair trade, although this makes up a tiny portion of sales and has a negligible impact on farmers compared with organic channels (Laguna 2008).

10 See Laguna (2000) for discussion.

11 For more complete discussion on Isabella and the role of intermediaries in Bolivian quinoa trade, see Ofstehage 2010.

12 The names of all individuals in this paper have been replaced with pseudonyms.

13 Farmers even elaborated on different degrees of "organicness."

14 Source for map of Bolivia (http://www.embajadade bolivia.com.ar/images/mapa01gde.gif); source for map of Los Lipez (http://www.delipez.org).

\section{References}

Aragon, Lorraine. 2001. Circulation and Sequestration in Split Markets: Informal Stewardship for Expressive Cultural Productions. Anthropology of Work Review 19(2).

Arce, Alberto. 2009. Living in Times of Solidarity: Fair Trade and the Fractured Life Worlds of Guatemalan Coffee Farmers. Policy Arena. Journal of International Development 21:1031-1041.

- , and Norman Long. n.d.. Work in Progress Manuscript. Wageningen, Netherlands: Wageningen University. 


\section{Anthropology of Work Review}

Barham, Elizabeth. 2003. Translating Terroir: The Global Challenge of French AOC Labeling. Journal of Rural Studies 19:127-138.

Bautista Muraña, Amado, Estanislao Quispe Calcina, and Aquiles Copa Cayo. 2006. Historia Contemporánea de Los Lipez. Uyuni: Centro Inti.

Benni, Nadja El, and Sophie Reviron. 2009. Geographical Indications: Review of Seven CaseStudies World Wide. NCCR Working Paper Number 2009/15. Bern, Switzerland: Swiss National Centre of Competence in Research.

Blum, Volkmar. 1995. Campesinos y Teoricos Agrarios: Pequena Agricultura en los Andes del Sur del Peru. Lima: Instituto de Estudios Peruanos.

Bowen, Sarah, and Ana Valenzuela Zapata. 2009. Geographical Indications, Terroir, and Socioeconomic and Ecological Sustainability: The Case of Tequila. Journal of Rural Studies 25:108-119.

Buechler, Hans, and Judith-Maria Buechler. 1996. The World of Sophía Velasquez: The Autobiography of A Bolivian Market Vendor. New York: Columbia University Press.

Daviron, Benoît, and Stefano Ponte. 2005. The Coffee Paradox: Global Markets, Commodity Trade and the Elusive Promise of Development. London: Zed Books.

Gerkey, Drew. 2001. Abandoning Fish: The Vulnerability of Salmon as a Cultural Resource in a PostSoviet Commons. Anthropology of Work Review 32(2).

Goldstein, Daniel, and Fatimah Williams Castro. 2006. Creative Violence: How Marginal People Make News in Bolivia. Journal of Latin American Anthropology 11(2):380-407.

González de Olarte, Efraín. 1994. En las Fronteras del Mercado: Economía Política del Campesinado en el Perú. Lima: Instituto de Estudios Peruanos.

Gudeman, Stephen. 1999. The Anthropology of Economy. Malden, MA: Blackwell Publishers.

Guthman, Julie. 2007. The Polanyian Way? Voluntary Food Labels as Neoliberal Governance. Antipode 39(3):456-478.
Jaffee, Daniel. 2007. Brewing Justice: Fair Trade Coffee, Sustainability, and Survival. Berkley, CA: University of California Press.

Laguna, Pablo. 2000. El Impacto del Desarrollo del Mercado de la Quinua en los Sistemas Productivos y Modos de Vida del Altiplano Sur Boliviano. Sistematización de la Experiencia de Inserción al Mercado de la Quinoa. La Paz: ANAPQUI.

2008. Grano Pequeño, Mercado Grande, Grandes Apuestas: Estudiando los Limites de la Regulación Estatal Francesa del Comercio Justo a Partir del Caso de la Quinua. Paper presented at the 3rd Colloque International sur le Commerce Equitable, CIRAD, Montpellier, May 14-16.

Mauss, Marcel. 2002. The Gift: The Form and Reason for Gift Exchange in Archaic Societies. London: Routledge Classics.

Miller, Daniel. 1998. Conclusion: A Theory of Virtualism. In Virtualism: A New Political Economy. Daniel Miller and James Carrier, eds. Pp. 187-216. Oxford: Berg.

2002. Turning Callon the Right Way Up. Economy and Society 31(2):218-223.

Ofstehage, Andrew. 2010. The Gift of the Middleman: Ethnography of Quinoa Trading Networks in Los Lipez of Bolivia. Master's Thesis, Rural Development Sociology Chairgroup, Wageningen University.

Pendergrast, Mark. 2010. Uncommon Grounds: The History of Coffee and How It Changed the World. New York: Basic Books.

Polanyi, Karl. 2001. The Great Transformation: The Political and Economic Origins of Our Time. Boston, MA: Beacon Press.

Renting, Henk, Terry K. Marsden, and Jo Banks. 2003. Understanding Alternative Food Networks: Exploring the Role of Short Food Supply Chains in Rural Development. Environment and Planning 35(3):393-411.

Shiva, Vandana. 1997. Biopiracy: The Plunder of Nature and Knowledge. Cambridge, MA: South End Press.

Tortorelli, Cristina Errázuriz. 2010. Indicaciones Geográficas y Denominaciones de Origen: Propiedad Intelectual en Progreso. Revista Chilena de Derecho 37(2):207-239. 


\section{Anthropology of Work Review}

Victor-Ragonese, Natalio, and Francisco QuisbertSalinas. 2005. Grano de Oro y Asalto. Cochabamba: Cenda.

Vitrolles, Delphine. 2011. When Geographical Indication Conflicts with Food Heritage Protection. Anthropology of Food. Electronic document, http:// aof.revues.org/index6809.html, accessed June 16, 2011.

DOI:10.1111/j.1548-1417.2011.01062.x 